\title{
Etikkvurdering ved innføring av ny behandling
}

Vegard Bruun Wyller og medarbeidere skriver i dette nummer av Tidsskriftet om erfaringene med perkutan innsetting av kunstig pulmonalklaff hos ti pasienter med medfødt hjertefeil (1). Resultatene er gode. Det oppsto ingen livstruende komplikasjoner, liggetiden var kort, alle rapporterte symptombedring etter seks måneder og bedringen av høyre ventrikkels hemodynamikk vedvarte. Så langt så godt. Men hva om resultatene ikke hadde vært tilfredsstillende? Hva om flere pasienter hadde fått livstruende komplikasjoner i tilslutning til prosedyren eller døde? Innføringen av behandlingstilbudet ble ikke fremlagt for regional etisk komité (REK). Det ble heller ikke innhentet skriftlig samtykke. Ingen betviler forfatternes generelle faglige dyktighet eller vilje til å gjøre godt. Likevel undres man. Forfatterne argumenterer for å unngå behandling i etikkomiteen. Vi i komiteen ser gjentatte eksempler på at innføring av ny teknologi er blitt en arena der tolking og praksis av krav til hva som er forsvarlig, enten mangler eller omgås. Altfor mye er overlatt til leger som ikke sjelden vil være først ute globalt, nasjonalt eller på eget sykehus. Dette er ikke forsvarlig. Innføring av ny teknologi må som hovedregel innledes med en studie lagt opp etter vitenskapelige prinsipper.

La oss tenke oss at vi kan skru tiden tilbake til 2007 da den første av disse ti pasientene ble behandlet på Rikshospitalet. Hvilke alternativer hadde man? Det var da bare sju år siden den første vellykkede kateterbaserte innsettingen av pulmonalklaff ble utført. Metoden ble antatt å by på flere fordeler sammenliknet med standard åpen hjertekirurgi. Den nye metoden var brukt på noen hundretalls pasienter, men ingen randomiserte studier forelå. Tilstanden som skulle behandles er sjelden,og antall pasienter som vil være aktuelle for slik prosedyre er meget lavt, sannsynligvis under fem per år.

Avklaring 1. Er det riktig å tilby metoden? Er det pasientgrunnlag for å sette i gang prosedyren i Norge? Ville det ikke være mer forsvarlig å sende pasientene til en klinikk der behandlingen gis regelmessig? Antall pasienter aktuelle for prosedyren per år ligger så lavt at det må by på problemer å opprettholde et minimum av erfaring ut fra internasjonale kriterier. Argumentet for å sentralisere disse pasientene utenlands bør veie tungt, særlig hvis man kunne sende pasientene til et sykehus som var opptatt av å samle mange nok til å gjennomføre en sammenliknende studie.

Avklaring 2. La oss tenke oss at økonomiske eller andre forhold umuliggjorde pasienteksport. Da blir neste oppgave å gjøre en vurdering av om man har tilstrekkelig lokal ekspertise til å gjennomføre behandlingen. Wyller og medarbeidere må ha vurdert at det hadde de, noe jeg heller ikke finner grunn til å betvile. Jeg bekymrer meg derimot over deres fremgangsmåte ved igangsetting av behandlingen og holdningen til vurdering i regional etisk komité.

Avklaring 3. De faglige forutsetningene ble funnet, men ble det skrevet protokoll for dette kliniske forskningsprosjektet? Det fremgår ikke av artikkelen om så ble gjort før klaffeimplantasjonene ble startet. Wyller og medarbeidere er på ville veier når de skriver: «Ettersom fagmiljøet har betraktet innsetting av kunstig pulmonalklaff som et nytt klinisk tilbud og ikke som eksperimentell behandling, blir ikke samtykke gitt skriftlig. Av samme grunn ble heller ikke Regional komité for medisinsk forskningsetikk (REK) involvert da denne behandlingsmetoden ble innført» (1). Det er vanskelig å tolke dette annerledes enn at forfatterne mener innsetting av perkutan klaff er etablert behandling. Men noe man selv aldri har gjort før, kan ikke karakteriseres som etablert behandling selv om andre hadde spredte, ikke-systematiserte erfaringer med metoden. I norsk medisin har vi $i$ en årrekke benyttet begrepet «utprøvende behandling» for behandling som ligger i grenseområdet mellom eksperimentell behandling og etablert medisin. Utprøvende behandling er imidlertid også forskning. I forskriften om prioritering av helsetjenester defineres det som «behandling som utprøves som ledd i en vitenskapelig studie, men der kravene til fullverdig dokumentasjon i forhold til etablert behandling ennå ikke er tilfredsstillende«(2). Innsetting av perkutan klaff ved Rikshospitalet i 2007 fylte alle krav til utprøvende behandling.

Avklaring 4. I og med at utprøvende behandling er forskning, skal det søkes godkjenning av regional etisk komié. Det er skuffende at de ansvarlige for denne studien ikke har sett fordelen med å få en ekstern vurdering av hva de var i ferd med å starte og som hadde flere usikre elementer. Det er lett å se seg blind på etiske problemer ved egen virksomhet (3). Etikkomiteen ville også vektlagt hvordan informasjonen til forsøksdeltakerne ble gitt. Den ville krevd innhenting av skriftlig samtykke, noe som ikke ble gjort her.

Wyller og medarbeidere er ikke de første som innfører ny behandling på denne uheldige måten. Det er ikke mer enn et par måneder siden Busund og medarbeidere argumenterte for at en annen prospektiv studie med liknende teknologi ikke var forskning, men kvalitetssikring $(4,5)$. Mye taler for at inndelingen i eksperimentell, utprøvende og etablert behandling bør erstattes med inndeling i fase 1-4 som er vel kjent fra legemiddelutprøvning. Et annet grep for å skaffe pasienter tryggere tilbud når ny teknologi skal innføres, er at initiativtakerne må dokumentere at visse minimumskrav er oppfylt. Mini health technology assessment (mini-HTA) er et verktøy/sjekkliste som skal bidra til å belyse effekt, sikkerhet, kostnader og organisatoriske konsekvenser knyttet til metoden. Departementet foreslo nylig i Nasjonal helse- og omsorgsplan (6) at institusjoner som ønsker å ta i bruk en ny metode, først må gjennomføre en slik minisjekk som etterspør mange av elementene $\mathrm{i}$ behandlingen i de regionale etiske komiteene. Her er det behov for samordning. Men viktigst er det at de som driver nybrott, ser allierte der de nå ser motstandere.

\section{Stein A. Evensen}

s.a.evensen@medisin.uio.no

Stein A. Evensen (f.1942) er professor ved Institutt for klinisk medisin ved Universitetet i Oslo og overlege ved Oslo universitetssykehus, Rikshospitalet.

Oppgitte interessekonflikter: Forfatteren er leder av en regional etisk komité

Litteratur

1. Wyller VB, Aaberge L, Thaulow E et al. Perkutan kateterbasert innsetting av kunstig pulmonalklaff ved medfødt hjertefeil. Tidsskr Nor Legeforen 2011; 131 1289-93.

2. Sak 09/64. Fra «eksperimentell» via «utprøvende» til «etablert behandling». Oslo: Nasjonalt råd for kvalitet og prioritering i helsetjenesten, 2009 www.kvalitetogprioritering.no/Saker/12765.cms

Frich L. Etablert, utprøvende eller eksperimentell? Tidsskr Nor Legeforen 2011; 131: 331 .

4. Steigen TK, SchiveB, Næsheim T et al. Transkateter aortaventilimplantasjon ved aortastenose. Tidsskr Nor Legeforen 2011; 131: 343-8.

. Busund R, Steigen TK, Næsheim T et al. Kvalitetsikring, ikke forskning. Tidsskr Nor Legeforen 2011; 131: 342.

6. St.meld. nr. 16 (2010-2011). Nasjonal helse-og omsorgsplan (2011-2015). 